\title{
Green silver nanoparticles: novel therapeutic potential for cancer and microbial infections
}

\begin{abstract}
The nanomedicine is opening borders by designing and testing both novel devices for clinical diagnosis and new therapies based on chemical nanostructures that exert their direct biological action or acting as pharmacological carriers. The development of new ecofriendly chemical synthesis methods opened a field of opportunity for nanomedicine and in the last years a great number of metallic nanoparticles have been synthesized through green chemical synthesis using natural plant extracts (leaf, stem, peel, bark, fruits). This review it shows an overview of the current status with silver nanoparticles synthesized by green chemical methods regarding their therapeutic potential for use in the treatment of microbial infections and cancer. The analysis carried out in recent publications shows that green silver nanoparticles have high antimicrobial activity (antibacterial, antifungal and antiviral) which can be enhanced with the addition of functional groups contained in the natural extracts used during the synthesis. In addition, there are many studies in different types of cancer that show the anticancer activity of green silver nanoparticles. This study shows that green synthesis has improved the selectivity of biological action and the biocompatibility of silver nanoparticles, these results are encouraging for treatment of cancer and microbial infections in humans.
\end{abstract}

Keywords: Green silver nanoparticles, Cancer, Antimicrobial, Natural extract, Nanomedicine
Volume 6 Issue 4 - 2017

\author{
Adolfo Virgen-Ortiz,' Alejandro Apolinar- \\ Iribe' \\ 'Centro Universitario de Investigaciones Biomedicas, \\ Universidad de Colima, Colima, Mexico \\ ${ }^{2}$ Departamento de Fisica, Universidad de Sonora, Mexico
}

Correspondence: Adolfo Virgen-Ortiz, Centro Universitario de Investigaciones Biomedicas, Universidad de Colima. Av. 25 de Julio No. 965, Colonia Villa San Sebastian, Colima, C.P. 28045, Mexico Email avirgen@ucol.mx

Received: October 29, 2017 | Published: November 30, 2017

\section{Introduction}

As a result of the development of nanotechnology in the last decade, silver nanoparticles emerged as an interesting alterative for the treatment of antimicrobial diseases and cancer, but its toxicological effects and its low biocompatibility were limiting its potential for clinical application. ${ }^{1-3}$ The development of biosynthetic methods to obtain silver nanoparticles based on silver ions and natural plant extracts (Rich in reducing, capping, and stabilizing agents) radically changes the perspective on its adverse effects, since this green synthesis method allows obtaining silver nanoparticles with more biocompatibility. ${ }^{4-7}$ The present review aims to show an overview of the therapeutic potential of silver nanoparticles synthesized with natural plant extracts for the treatment of microbial infections and cancer, this analysis is based on recent publications.

\section{Discussion}

\section{Antimicrobial activity}

A large number of green silver nanoparticles have been synthesized using plant extracts as a reaction medium which provides reducing and stabilizing agents; most studies have been carried out with natural plants that have ethnomedical use in humans. As shown in Table $1,^{8-27}$ the antimicrobial effect of the green silver nanoparticles, mainly their antibacterial ${ }^{8-25}$ and antifungal action, ${ }^{10,12-14,17,18,23-25}$ has been widely reported. It is important to mention that despite a wide variety of studies existing in the literature, antimicrobial activity has generally been evaluated in the same microorganisms even though there is a large amount of bacteria, fungi and viruses of clinical importance that could be studied. Also, when existing studies are analyzed (Table 1), most suggest that biosynthesized silver nanoparticles are biocompatible and may have therapeutic use potential in humans; however, if we review the studies summarized in Table 1 very few carry out biocompatibility tests in normal cells. , $10,14,15,18,26,27^{\text {These tests }}$ provide crucial information on the ranges of safety and cytotoxicity of the biosynthetized nanoparticles, information that result fundamental to can be designed future experiments with biomedical applications in preclinical and clinical models. Another important fact is about the physical nature of the nanoparticles with respect to their size, most of the studies obtained nanoparticles with sizes greater than $10 \mathrm{~nm}$ in diameter; ${ }^{8,10-17,19-27}$ it would be interesting to know their effects with sizes smaller than $10 \mathrm{~nm}$ since there is evidence that their biological effects also dependent on size. ${ }^{28}$ Furthermore, for a better comparative analysis of the therapeutic potential of green silver nanoparticles, it is important to include in future experiments reference drugs that are currently the most used and effective in antimicrobial therapy in humans (cephalosporins, quinolones, and macrolides), ${ }^{29}$ since most studies existing do not include used-commercial drugs as control $^{8-9,11,13-16,18,20-21}$ or it is included drugs used in the past. Finally, the plant extracts used in the green synthesis of nanoparticles contain a large variety of functional groups that can be added to the chemical structure of the silver nanoparticle, in this sense the existing studies have not fully evaluated the role that can have the chemical functionalization in the biological activity of the nanoparticles, the studies included in the present review discuss very little to the regard, being a critical factor that can explain the variability in the antimicrobial effect of the different types of silver nanoparticles that are biosynthesized. Another relevant aspect is that green silver nanoparticles could be an innovative alternative to reduce resistance to antibiotics a serious problem responsible for the increase in deaths worldwide. $^{29}$

\section{Anticancer activity}

Green synthesis of silver nanoparticles using plant extracts offers a simple, fast and economical method to generate new molecules with anticancer potential as has been reported in recent years as is shows in Table 2. Recent studies with biosynthesized silver nanoparticles provide encouraging information focused on finding novel therapies for 
different types of cancer, but there are challenges for these molecules to become clinically useful. A key point in anticancer therapy is to have drugs or molecules that are highly selective to kill cancer cells. In the literature there are green silver nanoparticles with anticancer activity but their cytotoxic effects have not been evaluated in normal cells, ${ }^{21,30,33,37,39,42}$ others show that there is little selectivity for cancer cells ${ }^{14,34}$ and other studies show encouraging anticancer activity due to a better degree of selectivity. ${ }^{32,35,36,40,41,43,45}$ An advantage of the use of medicinal plant extracts is the opportunity to be able to functionalize silver nanoparticles to enhance their anticancer effect and improve their specificity of action on cancer cells without affecting non-tumor cells; this represents a challenge for scientists. To date, most studies have evaluated the anticancer activity of green silver nanoparticles using in vitro assays and cell lines. Other challenge is carry out future experiments on in vivo cancer models with immunocompetent and immunosuppressed animals to evaluate anticancer activity of green silver nanoparticles and its toxicology. Current reports show that green silver nanoparticles have great potential as future therapies against cancer, but knowledge about their side effects in non-target cells and organs is very poor and requires more research. Another opportunity that results from the analysis of this minireview is to study the anticancer activity of green silver nanoparticles on other types of cancer such as leukemia, lymphoma, myeloma, ovary, pancreas, thyroid, brain, kidney, skin. Moreover, the differences in anticancer activity and biocompatibility in the studies analyzed in the present work may be due to the size of silver nanoparticle and the functional groups since the plants used for the synthesis have differences in their chemical composition

Table I Antimicrobial action of green silver nanoparticles and biocompatibility.

\begin{tabular}{|c|c|c|c|c|}
\hline Reference & Shape/Size & Plant Used for the Synthesis & Microorganism & Biocompatibility in Normal Cell \\
\hline [8] & Spherical 7I nm & Aloe Vera leaf & S. epidermidis, P. aeruginosa & Yes $\mathrm{IC}_{50}>2.5 \mu \mathrm{g} / \mathrm{mL}$ \\
\hline [9] & $\begin{array}{l}\text { spherical } \\
7.4 \mathrm{~nm}\end{array}$ & Hydrocotyle rotundifolia leaf & E. coli & n.e \\
\hline$[10]$ & Spherical I5-30nm & Thalictrum foliolosum root & $\begin{array}{l}\text { E. coli, K. pneumonia, P. diminuta, B. subtilis, S. aureus, } \\
\text { M. smegmatis, C. albicans, T. rubrum, A. versicolor, } \\
\text { A. niger }\end{array}$ & Yes $I_{50}>62.5 \mu g / m L$ \\
\hline$[\mathrm{II}]$ & Spherical $16 \mathrm{~nm}$ & Ficus benghalensis leaf & E.coli & n.e \\
\hline [12] & Spherical 9-32 nm & Longan peel & S. aureus, B. subtilis, E. coli, P. aeruginosa, C. albicans & n.e \\
\hline [13] & Spherical $30-40 \mathrm{~nm}$ & O. heracleoticum L leaf & $\begin{array}{l}\text { S. aureus, E. coli, P. aeruginosa, K. pneumonia, S. } \\
\text { pneumonia, C. albicans }\end{array}$ & n.e \\
\hline$[14]$ & Spherical $13 \mathrm{~nm}$ & Alpinia katsumadai seeds & S. aureus, B. subtilis, E. coli, P. aeruginosa C. albicans & Yes 7.5- $15 \mu \mathrm{g} / \mathrm{mL}$ \\
\hline$[15]$ & Spherical & Protium serratum leaf & P. aeruginosa, E. coli, B. subtilis & Yes $\mathrm{IC}_{50}, 600 \mu \mathrm{g} / \mathrm{mL}$ \\
\hline [16] & Spherical $20 \mathrm{~nm}$ & Eriobotrya japonica leaf & E. coli, S. aureus & n.e \\
\hline$[17]$ & Spherical 7-44 nm & Syzygium alternifolium leaf & $\begin{array}{l}\text { B. subtilis, S. aureus, E. coli, } K \text {. pneumonia, } P \text {. vulgaris, } \\
\text { P. aeruginosa, S. typhimurium, A. solani, A. flavus, } A \text {. } \\
\text { niger, } P \text {. chrysogenum, T. harzianum. }\end{array}$ & n.e \\
\hline$[18]$ & Spherical $7 \mathrm{~nm}$ & Rumex hymenosepalus root & $\begin{array}{l}\text { E. coli, S. aureus, S. serovar typhi, P. aeruginosa, L. } \\
\text { monocytogenes, C. albicans }\end{array}$ & Yes $\mid C_{50} \gg 500 \mu g / m L$ \\
\hline [19] & Spherical $16-30 \mathrm{~nm}$ & Phyllanthus amarus, whole plant & P. aeruginosa & n.e \\
\hline [20] & Spherical 22-32 nm & $\begin{array}{l}\text { Ricinus Communis, Catha Edulis, } \\
\text { Helianthus Annuus leaf }\end{array}$ & E.coli, S. aureus & n.e \\
\hline$[21]$ & Spherical $22-30 \mathrm{~nm}$ & Ailanthus excelsa leaf & E. coli, K. pneumonia, S. aureus, P. aeruginosa & n.e \\
\hline [22] & Spherical $16 \mathrm{~nm}$ & Pongamia pinnata seeds & E. coli & n.e \\
\hline [23] & Cubic-hexagonal $30 \mathrm{~nm}$ & Argemone maxicana leaf & E. coli, $P$. aeruginosa, $A$. flavus & n.e \\
\hline [24] & Spherical $516 \mathrm{~nm}$ & Acalypha indica, whole plant & $\begin{array}{l}\text { B. subtilis, S.aureus, P.aeruginosa, E. coli C.albicans, } \\
\text { A. niger }\end{array}$ & n.e \\
\hline [25] & Spherical 0-50 nm & Ocimum sanctum leaf & $\begin{array}{l}\text { E. coli , P. vulgaris, S. aureus, S. saprophyticus } C \text {. } \\
\text { albicans, C. tropicalis, C. krusei, C. Kefyr, A. niger A. } \\
\text { flavus, A. fumigatus }\end{array}$ & n.e \\
\hline [26] & Spherical $42 \mathrm{~nm}$ & Cinnamomum cassia & Avian influenza virus subtype $\mathrm{H} 7 \mathrm{~N} 3$ & Yes $I C_{50} \gg>500 \mu \mathrm{g} / \mathrm{mL}$ \\
\hline [27] & Spherical $27 \mathrm{~nm}$ & Garcinia imberti & E. faecium, S. sciuri, E. faecalis. & Yes $I_{50}>75 \mu \mathrm{g} / \mathrm{mL}$ \\
\hline
\end{tabular}

n.e $=$ It was not evaluated

Table 2 Anticancer action of green silver nanoparticles and biocompatibility

\begin{tabular}{llllll}
\hline References & Shape/Size & Plant Used for the Synthesis & Type of Cancer & IC $_{50}$ & $\begin{array}{l}\text { Biocompatibility in } \\
\text { Normal Cell IC }_{50}\end{array}$ \\
\hline$[30]$ & Spherical $5-47 \mathrm{~nm}$ & Vitex negundo Linn leaf & Colon & $20 \mu \mathrm{g} / \mathrm{mL}$ & n.e \\
{$[31]$} & Spherical $91 \mathrm{~nm}$ & Taxus baccata needles & Breast & $0.25-5 \mu \mathrm{g} / \mathrm{mL}$ & n.e \\
{$[32]$} & Spherical $15-18 \mathrm{~nm}$ & Curculigo orchioides rhizome & Breast & $19 \mu \mathrm{g} / \mathrm{mL}$ & $42 \mu \mathrm{g} / \mathrm{mL}$ \\
{$[33]$} & Spherical $20-40 \mathrm{~nm}$ & Piper nigrum & Breast Pharinx & $52 \mu \mathrm{g} / \mathrm{mL} 43 \mu \mathrm{g} / \mathrm{mL}$ n.e \\
{$[12]$} & Spherical 9-32 nm & Dimocarpus longan peel & Prostate & $5-10 \mu \mathrm{g} / \mathrm{mL}$ & n.e \\
{$[13]$} & Spherical $30-40 \mathrm{~nm}$ & O. heracleoticum L leaf & Breast & $50-100 \mu \mathrm{g} / \mathrm{mL}$ & n.e \\
{$[14]$} & Spherical $13 \mathrm{~nm}$ & Alpinia katsumadai seeds & Gastric & $7.5-15 \mu \mathrm{g} / \mathrm{mL}$ & $7.5-15 \mu \mathrm{g} / \mathrm{mL} / \mathrm{mL}$ \\
\hline
\end{tabular}


Table Continued...

\begin{tabular}{|c|c|c|c|c|c|}
\hline References & Shape/Size & Plant Used for the Synthesis & Type of Cancer & $I_{50}$ & $\begin{array}{l}\text { Biocompatibility in } \\
\text { Normal Cell } \text { IC }_{50}\end{array}$ \\
\hline$[21]$ & Spherical 22-30 nm & Ailanthus excelsa leaf & Breast & $265 \mu \mathrm{g} / \mathrm{mL}$ & n.e \\
\hline$[34]$ & $\begin{array}{l}\text { Spherical } 20-50 \mathrm{~nm} \\
8-20 \mathrm{~nm}\end{array}$ & Green tea Coffee & Cervical & $\begin{array}{l}14 \mu \mathrm{g} / \mathrm{mL} \\
655 \mathrm{mg} / \mathrm{mL}\end{array}$ & $\begin{array}{l}5 \mu \mathrm{g} / \mathrm{mL} \\
272 \mathrm{mg} / \mathrm{mL}\end{array}$ \\
\hline \multirow[t]{2}{*}[35]{} & Spherical $15 \mathrm{~nm}$ & Lonicera hypoglauca flower & Breast & $<<500 \mu \mathrm{g} / \mathrm{mL}$ & $>>500 \mu \mathrm{g} / \mathrm{mL}$ \\
\hline & & & Lung & $>20 \mu \mathrm{g} / \mathrm{mL}$ & \\
\hline \multirow[t]{2}{*}[36]{} & Spherical 5-15 nm & Panax ginseng fresh leaf & Breast & $>10 \mu \mathrm{g} / \mathrm{mL}$ & $>2 \mathrm{mg} / \mathrm{mL}$ \\
\hline & & & Liver & $>10 \mu \mathrm{g} / \mathrm{mL}$ & \\
\hline [37] & Spherical 54-89 nm & Ficus carica fruit & Breast & $12 \mu g / m L$ & n.e \\
\hline \multirow{4}{*}[36]{} & Spherical 5- $50 \mathrm{~nm}$ & Syzygium aromaticum & Breast & $60 \mu \mathrm{g} / \mathrm{mL}$ & ne \\
\hline & spiler real s- Jo illi & 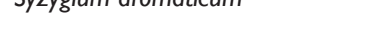 & Lung & $50 \mu \mathrm{g} / \mathrm{mL}$ & II.e \\
\hline & & & Lung & $0.9 \mu \mathrm{g} / \mathrm{mL}$ & \\
\hline & & & Cervical & $\mathrm{I} \mu \mathrm{g} / \mathrm{mL}$ & \\
\hline \multirow[t]{3}{*}{ [39] } & Spherical 5- $21 \mathrm{~nm}$ & Ficus religiosa leaf & Liver & I.I $\mu \mathrm{g} / \mathrm{mL}$ & n.e \\
\hline & & & Colon & $1.7 \mu g / m L$ & \\
\hline & & & Neuroblastoma & $3.8 \mu \mathrm{g} / \mathrm{mL}$ & \\
\hline [40] & Spherical 94 nm & Azadirachta indica leaf & Lung & 120 ppm & >> 24 ppm \\
\hline$[4 I]$ & Spherical 3-10 nm & Mentha arvensis leaf & Breast & $6.25 \mu \mathrm{g} / \mathrm{mL}$ & $12.5 \mu \mathrm{g} / \mathrm{mL}$ \\
\hline [42] & Spherical, hexagonal & Rorara officinalis & Lung & $5 \mu g / m L$ & \\
\hline [42] & $30-80 \mathrm{~nm}$ & Dorago oाticinals & Cervical & $2 \mu g / m L$ & n.e \\
\hline$[43]$ & Polygonal $100-150 \mathrm{~nm}$ & Dendropanax morbifera leaf & Lung & $10-100 \mu g / m L$ & $\sim 100 \mu \mathrm{g} / \mathrm{mL}$ \\
\hline$[44]$ & Spherical $37 \mathrm{~nm}$ & Coriandrum sativum leaf & Breast & $30 \mu \mathrm{g} / \mathrm{mL}$ & n.e \\
\hline [45] & Spherical 6-27 nm & Taxus yunnanensis leaf & Liver & $28 \mu \mathrm{g} / \mathrm{mL}$ & $81 \mu \mathrm{g} / \mathrm{mL}$ \\
\hline
\end{tabular}

n.e $=$ It was not evaluated.

\section{Conclusion}

Currently, a large number of silver nanoparticles have be synthesized through green chemical synthesis using mainly medicinal plant extracts, these nanoparticles are generally spherical in shape, chemically stable and their method of production is simple, fast, low cost and ecofriendly. These green nanoparticles have antimicrobial and anticancer activity with high therapeutic potential for biomedical applications, but future experiments are needed to improve its selectivity on cancer cells, biocompatibility in normal cells and toxicological tests in preclinical models that validate its potential clinical application. The green silver nanoparticles open a novel pathway for treatment of the cancer and microbial infections in humans.

\section{Acknowledgements}

There were no funding sources for the study.

\section{Conflicts of Interest}

The authors declare that they have no conflict of interests. A.V.O designed and wrote manuscript; A.A.I. participated in design and wrote manuscript.

\section{References}

1. Vazquez-Muñoz R, Borrego B, Juárez-Moreno K et al. Toxicity of silver nanoparticles in biological systems: Does the complexity of biological systems matter? Toxicology Letters. 2017;5(276):11-20.

2. Dakal TC, Kumar A, Majumdar RS et al. Mechanistic Basis of Antimicrobial Actions of Silver Nanoparticles. Frontiers in Microbiology. 2016;7:1831

3. Riaz Ahmed KB, Nagy AM, Brown RP et al. Silver nanoparticles: Significance of physicochemical properties and assay interference on the interpretation of in vitro cytotoxicity studies. Toxicology In vitro 2017;38:179-192.
4. Rajeshkumar S, Bharath LV. Mechanism of plant-mediated synthesis of silver nanoparticles - A review on biomolecules involved, characterisation and antibacterial activity. Chemico Biological Interactions. 2017;273:219-227.

5. Patil MP, Kim GD. Eco-friendly approach for nanoparticles synthesis and mechanism behind antibacterial activity of silver and anticancer activity of gold nanoparticles. Applied Microbiology and Biotechnology. 2017;101(1):79-92.

6. Velusamy P, Kumar GV, Jeyanthi V, et al. Bio-Inspired Green Nanoparticles: Synthesis, Mechanism, and Antibacterial Application. Toxicological Research. 2016;32(2):95-102.

7. Srikar S, Giri D, Pal D, et al. Green Synthesis of Silver Nanoparticles: A Review. Green and Sustainable Chemistry. 2016;6:34-56.

8. Tippayawat P, Phromviyo N, Boueroy P, et al. Green synthesis of silver nanoparticles in aloe vera plant extract prepared by a hydrothermal method and their synergistic antibacterial activity. Peer J. 2016;4:e2589.

9. Kumari R, Brahma G, Rajak S, et al. Antimicrobial activity of green silver nanoparticles produced using aqueous leaf extract of Hydrocotyle rotundifolia. Oriental Pharmacy and Experimental Medicine. 2016;16:195-201.

10. Hazarika SN, Gupta K, Shamin KNAM, et al. One-pot facile green synthesis of biocidal silver nanoparticles. Materials Research Express. 2016;3(7):075401.

11. Saxena A, RM Tripathi RM, Zafar F, et al. Green synthesis of silver nanoparticles using aqueous solution of Ficus benghalensis leaf extract and characterization of their antibacterial activity. Material letters. 2012;67:91-94

12. He Y, Du Z, Ma S, et al. Biosynthesis, Antibacterial Activity and Anticancer Effects Against Prostate Cancer (PC3) Cells of Silver Nanoparticles Using Dimocarpus Longan Lour. Peel Extract. Nanoscale Research Letters. 2016;11(1):300.

13. Rajendran R, Ganesan N, Balu SK, et al. Green synthesis, characterization, antimicrobial and cytotoxic effects of silver nanoparticles using Origanum Heracleoticum L. leaf extract. International Journal of Pharmacy and Pharmaceutical Sciences. 2015;7(4):288-293. 
14. He Y, Weia F, Mab Z, et al. Green synthesis of silver nanoparticles using seed extract of Alpinia katsumadai, and their antioxidant, cytotoxicity, and antibacterial activities. Royal Society of Chemistry Advances. 2017;7: 39842-39851.

15. Mohanta YK, Panda SK, Bastia AK, et al. Biosynthesis of Silver Nanoparticles from Protium serratum and Investigation of their Potential Impacts on Food Safety and Control. Front Microbiol. 2017;8:626.

16. Rao B, Tang RH. Green synthesis of silver nanoparticles with antibacterial activities using aqueous Eriobotrya japonica leaf extract. Advances in Natural Sciences: Nanoscience and Nanotechnology. 8 (2017);015014.

17. Yugandhar P, Savithramma N. Leaf Assisted Green Synthesis of Silver Nanoparticles from Syzygium Alternifolium (Wt.) Walp. Characterization and Antimicrobial Studies. Nano Biomedicine and Engineering. 2015;7(2):29-37.

18. Rodríguez-León E, Íñiguez-Palomares RA, Navarro RE, et al. Silver nanoparticles synthesized with Rumex hymenosepalus extracts: effective broad-spectrum microbicidal agents and cytotoxicity study. Artificial Cells Nanomedicine and Biotechnolology. 2017;21:1-13.

19. Singh K, Panghal M, Kadyan S, et al. Green silver nanoparticles of Phyllanthus amarus: as an antibacterial agent against multi drug resistant clinical isolates of Pseudomonas aeruginosa. J Nanobiotechnology. 2014;12:40.

20. Gebru H, Taddesse A, Kaushal J, et al. Green Synthesis of Silver Nanoparticles and their Antibacterial Activity. Journal of Surface Science and Technology. 2013;29(1-2):47-66.

21. Vinmathi V, Packia-Jacob SJ. A green and facile approach for the synthesis of silver nanoparticles using aqueous extract of Ailanthus excelsa leaves, evaluation of its antibacterial and anticancer efficacy. Bulletin of Material Sciences. 2015;38(3):625-628.

22. Beg M, Maji A, Mandal AK, et al. Green synthesis of silver nanoparticles using Pongamia pinnata seed: Characterization, antibacterial property,and spectroscopic investigation of interaction with human serum albumin. Journal of Molecular Recognition. 2016;30(1):e2565.

23. Singh A, Jaina D, Upadhyaya MK, et al. Green synthesis of silver nanoparticles using Argemone mexicana leaf extract and evaluation of their antimicrobial activities. Digest Journal of Nanomaterials and Biostructures. 2010;5(2):483-489.

24. Kumarasamyraja D, Jeganathan NS. Green synthesis of silver nanoparticles using aqueous Extract of Acalypha indica and its antimicrobial activity. International Journal of Pharma and Bio Sciences. 2013;4(3):469-476.

25. Rout Y, Behera S, Kumar Ojha A, et al. Green synthesis of silver nanoparticles using Ocimum sanctum (Tulashi) and study of their antibacterial and antifungal activities. Journal of Microbiology and Antimicrobials. 2012;4(6):103-109.

26. Fatima M, Sadaf-Zaidi NS, Amraiz D, et al. In vitro Antiviral Activity of Cinnamomum cassia and Its Nanoparticles Against H7N3 Influenza A Virus. Journal of Microbiology and Biotechnology. 2016;26(1):151-159.

27. Sri-Ramkumar SR, Sivakumar N, Selvakumar G, et al. Green synthesized silver nanoparticles from Garcinia imberti bourd and their impact on root canal pathogens and HepG2 cell lines. Royal Society of Chemistry Advances. 2017;7:34548.

28. Shin SW, Song IH, Um SH. Role of Physicochemical Properties in Nanoparticle Toxicity. Nanomaterials (Basel). 2015;5(3):1351-1365.

29. Fair RJ, Tor Y. Antibiotics and bacterial resistance in the 21 st century. Perspectives in Medicinal Chemistry. 2014;6:25-64.

30. Prabhua D, Arulvasua C, Babua G, et al. Biologically synthesized green silver nanoparticles from leaf extract of Vitex negundo L. induce growth-inhibitory effect on human colon cancer cell line HCT15. Process Biochemistry. 2013;48(2):317-324.

31. Abbasi-Kajani A, Bordbar AK, Esfahani SHZ, et al. Green synthesis of anisotropic silver nanoparticles with potent anticancer activity using Taxus baccata extract. Royal Society of Chemistry Advances. 2014;4:61394

32. Kayalvizhi T, Ravikumar S, Venkatachalam P. Green Synthesis of Metallic Silver Nanoparticles Using Curculigo orchioides Rhizome Extracts and Evaluation of Its Antibacterial, Larvicidal, and Anticancer Activity. Journal of Environmental Engineering. 2016;142(9):1.

33. Krishnan V, Bupesh G, Manikandan E, et al. Green Synthesis of Silver Nanoparticles Using Piper nigrum Concoction and its Anticancer Activity against MCF-7 and Hep-2 Cell Lines. Journal of Antimicrobial Agents. 2016;2:123.

34. Rónavári A, Kovács D, Igaz N, et al. Biological activity of greensynthesized silver nanoparticles depends on the applied natural extracts: a comprehensive study. International Journal of Nanomedicine. 2017;12:871-883.

35. Jang SJ, Yang IJ, Tettey CO, et al. In vitro anticancer activity of green synthesized silver nanoparticles on MCF-7 human breast cancer cells. Material Science Engineering C. 2016;68:430-435.

36. Castro-Aceituno V, Ahn S, Simu SY, et al. Anticancer activity of silver nanoparticles from Panax ginseng fresh leaves in human cancer cells. Biomededicine and Pharmacotherapy. 2016;84:158-165.

37. Justin Packia Jacob S, Siva Prasad VL, Sivasankar S, et al. Biosynthesis of silver nanoparticles using dried fruit extract of Ficus carica Screening for its anticancer activity and toxicity in animal models. Food Chem Toxicol. 2017;109:951-956.

38. Venugopal K, Rather HA, Rajagopal K, et al. Synthesis of silver nanoparticles (Ag NPs) for anticancer activities (MCF 7 breast and A549 lung cell lines) of the crude extract of Syzygium aromaticum. Journal of Photochemistry \& Photobiology, B: Biology. 2017;167(2017):282-289.

39. Nakkala JR, Mata R, Sadras SR. Green synthesized nano silver: Synthesis, physicochemical profiling, antibacterial, anticancer activities and biological in vivo toxicity. Journal of Colloid and Interface Science. 2017;499:33-45.

40. Kummara S, Patil MB, Uriah T. Synthesis, characterization, biocompatible and anticancer activity of green and chemically synthesized silver nanoparticles - A comparative study. Biomedicine \& Pharmacotherapy. 2016;84(2016):10-21.

41. Banerjee PP, Bandyopadhyay A, Harsha SN, et al. Mentha arvensis (Linn.) Mediated green silver nanoparticles trigger caspase 9dependent cell death in MCF7 and MDA-MB-231 cells. Breast Cancer (Dove Med Press). 2017;9:265-278.

42. Singh H, Du J, Yi TH Green and rapid synthesis of silver nanoparticles using Borago officinalis leaf extract: anticancer and antibacterial activities. Artificial Cells Nanomedicine and Biotechnology. 2017;45(7):1310-1316.

43. Wang C, Mathiyalagan R, Kim YJ et al. Rapid green synthesis of silver and gold nanoparticles using Dendropanaxmorbifera leaf extract and their anticancer activities. International Journal of Nanomedicine. 2016;11:3691-701.

44. Sathishkumar P, Preethi J, Vijayan R et al. Anti-acne, anti-dandruff and anti-breast cancer efficacy of green synthesised silver nanoparticles using Coriandrum sativum leaf extract. Journal of Photochemistry and Photobiology B. 2016;163:69-76.

45. Xia QH, Ma YJ, Wang JW Biosynthesis of Silver Nanoparticles Using Taxus yunnanensis Callus and Their Antibacterial Activity and Cytotoxicity in Human Cancer Cells. Nanomaterials (Basel). 2016;6(9):1. 